\title{
Caspase-2: A possible trigger of apoptosis induced in A-549 tumor cells by ZnPc photodynamic treatment
}

\author{
JAVIER CRISTÓBAL, JUAN C. STOCKERT, ANGELES VILLANUEVA, SANTIAGO RELLO-VARONA, \\ ANGELES JUARRANZ and MAGDALENA CAÑETE
}

Departamento de Biología, Facultad de Ciencias, Universidad Autónoma de Madrid, Cantoblanco, Madrid, Spain

Received October 3, 2005; Accepted November 29, 2005

\begin{abstract}
Photodynamic therapy applied to cell cultures represents a widely accepted experimental method to investigate molecular mechanisms that lead to apoptotic cell death. In this context the subcellular localization of photosensitizers seems to be a significant factor in order to determine the apoptotic pathway that could be activated. We have characterized the experimental conditions that induce apoptotic cell death in A-549 cells incubated with ZnPc and irrradiated with red light. Previously we have found that in this cell line the drug is localized in the Golgi apparatus after 3-h incubation. Indirect immunofluorescence analysis of the events that lead to apoptosis made possible the detection of caspase- 2 activation in the Golgi region immediately after photodynamic treatments. A few minutes later, the morphology of this organelle starts to disrupt and just $6 \mathrm{~h}$ after treatment the nuclei appear affected showing the fragmented appearance typical of apoptotic cell death. From this results we assume that following the photodynamic treatment of A-549 cells with $\mathrm{ZnPc}$, the activation of caspase- 2 in the Golgi apparatus could begin to initiate immediately the apoptotic process.
\end{abstract}

\section{Introduction}

Cell death in vivo and in vitro can occur under two general forms: necrosis and apoptosis. Apoptosis, also called programmed cell death, can be induced by a variety of stimuli. There is a growing interest in the analysis of apoptosis from diverse fields of biomedical research, but the apoptotic process is especially relevant in oncology. It is now generally accepted that the inhibition of apoptosis plays a role in the carcinogenic process $(1,2)$. Likewise, numerous studies have demonstrated

Correspondence to: Dr Magdalena Cañete, Departamento de Biología (A-115), Facultad de Ciencias, Universidad Autónoma de Madrid, C/Darwin no. 2, 28049-Madrid, Spain

E-mail:magdalena.canete@uam.es

Key words: cell photosensitization, zinc(II)-phthalocyanine, Golgi apparatus, apoptosis, caspase-2, A-549 cells that many anticancer drugs work, at least in part, by triggering apoptosis in neoplastic cells both in vitro and in vivo $(3,4)$.

The evaluation of apoptosis versus necrosis is an important parameter to determine the efficacy and the potential toxicity of a given treatment, allowing to adjust the more appropriate therapeutic protocol. Upon apoptosis induction, caspases (a family of specific aspartyl-cysteine proteases) are activated, mitochondria being of central significance for triggering the apoptotic process $(5,6)$. Accumulating evidence suggests that other organelles, including the Golgi apparatus, are also important points of integration of pro-apoptotic signalling or damage sensing (7). In this sense, photodynamic treatment applied to cell cultures represents a widely accepted experimental tool to investigate the molecular mechanism that leads to apoptotic cell death.

Photodynamic therapy (PDT) is a treatment for cancer that is based on the use of a photosensitizer (PS) and visible light to produce reactive oxygen species (ROS) within cells, mainly singlet oxygen $\left({ }^{1} \mathrm{O}_{2}\right)$. Several PSs currently used in PDT localize in different cell compartments $(8,9)$ such as mitochondria, lysosomes, endoplasmic reticulum or Golgi apparatus, and induce cell death by inducing apoptosis and/or necrosis as a function of treatment doses and cell type $(10,11)$. Most of the studies on cell death mechanisms were carried out using cell cultures, which are simplified models with respect to the situation in vivo. Since ${ }^{1} \mathrm{O}_{2}$ has a very short lifetime in cells, its intracellular targets must be located close to the sites where the sensitizer is accumulated (12).

In this work, we have characterized the localization of zinc(II)-phthalocyanine ( $\mathrm{ZnPc}$ ) in the Golgi apparatus of A-549 cells as well as the apoptotic cell death mechanism after red light irradiation. Indirect immunofluorescence analysis made possible the detection of caspase- 2 activation in the Golgi region, before this organelle starts to disrupt and before nuclei appear with the morphology typical of apoptotic cell death (13). From these results we can deduce that the Golgi apparatus, like other cell organelles, could have its own sensors for cellular damage, which would be involved in a precise signalling balance to determine either cell death or cell survival.

\section{Materials and methods}

Cell cultures. Human lung adenocarcinoma A-549 cells were grown as monolayer in Dulbecco's modified Eagle's medium (DMEM) supplemented with $10 \%(\mathrm{v} / \mathrm{v})$ foetal bovine serum 
(FBS), 50 units $/ \mathrm{ml}$ penicillin, $50 \mu \mathrm{g} / \mathrm{ml}$ streptomycin, and $1 \%$ (v/v) 0.2 M L-glutamine (all from Gibco). Cell cultures were performed in an incubator with $5 \%$ of $\mathrm{CO}_{2}$ plus $95 \%$ air at $37^{\circ} \mathrm{C}$. For photodynamic treatments cells were plated on $22 \mathrm{~mm}$ square coverslips within $35 \mathrm{~mm}$ culture dishes. In all cases subconfluent cell cultures were used.

Chemicals and preparation of liposomes. On account of its water insolubility, zinc(II)-phthalocyanine (ZnPc, Aldrich) was first dissolved in pyridine (Panreac) and then vehiculized in dipalmitoylphosphatidylcholine (DPPC, Sigma) liposomes following the method of Ginevra et al (14). ZnPc liposomes were sterilized by filtration through a Millipore ${ }^{\circledR}$ filter $(0.22 \mu \mathrm{m}$ in diameter) and diluted in DMEM with $1 \%$ FBS and $1 \%$ L-glutamine to obtain the appropriate drug concentration. Other chemicals used were: thiazolyl blue (MTT, Sigma), Triton X-100 (Sigma), dimethylsulfoxide (DMSO, Panreac), Hoechst 33258 (H-33258, Sigma), paraformaldehyde (BDH), Mowiol 40-88 (Sigma), and DePeX (Serva).

Experimental treatments. Cells were incubated with two different concentrations of $\mathrm{ZnPc}\left(5 \times 10^{-7} \mathrm{M}\right.$ and $\left.10-6 \mathrm{M}\right)$ in DPPC liposomes (hereafter simply $\mathrm{ZnPc}$ ) for 1,3 and $18 \mathrm{~h}$. After incubation, cells were washed twice with DMEM and then irradiated for $1,3,5,10$ or 15 min. Irradiation was carried out with a Reflecta slide projector equipped with a $150 \mathrm{~W}$ lamp. The light was filtered by a layer of water of $3 \mathrm{~cm}$ thickness to absorb heat and a red filter $(\lambda>600 \mathrm{~nm})$. The irradiation intensity received by the cell cultures was $21 \mathrm{~mW} /$ $\mathrm{cm}^{2}$, as measured with an M8 Spectrum Power Energymeter. Different methodological protocols were carried out either immediately after irradiation or $15 \mathrm{~min}, 30 \mathrm{~min}, 1,3,6$, and 24 h later.

Drug localization and organelle labelling. In order to analyze the localization of $\mathrm{ZnPc}$, cells grown on coverslips were incubated for 1, 2, 3 and $18 \mathrm{~h}$ with the drug, washed twice with PBS and observed by fluorescence microscopy under $\mathrm{UV}$ excitation. After $\mathrm{ZnPc}$ treatment and to analyze the possible participation of lysosomes in PS accumulation, cells were incubated with $1.5 \mathrm{ml} \mathrm{DMEM}$ and $20 \mu \mathrm{l}$ of $5 \times 10^{-6} \mathrm{M}$ acridine orange (AO, Gurr) for $1 \mathrm{~min}$, washed with PBS and visualized by fluorescence microscopy under blue light excitation. This concentration is lower than usual and therefore there is only a scarce accumulation of AO in lysosomes giving green fluorescence. This protocol allowed to avoid the orange-red AO emission in lysosomes, which could be difficult to distinguish from the red signal of $\mathrm{ZnPc}$.

Evaluation of cell survival. Cell survival was evaluated $24 \mathrm{~h}$ after experimental treatments by the MTT method (15). From a stock MTT solution ( $1 \mathrm{mg} / \mathrm{ml}$ in PBS), $0.1 \mathrm{ml}$ was added to the culture dishes containing $1.5 \mathrm{ml}$ DMEM (final MTT concentration: $62.5 \mu \mathrm{g} / \mathrm{ml}$ ). After incubation for $3 \mathrm{~h}$ at $37^{\circ} \mathrm{C}$ the culture medium was removed and the formazan precipitate dissolved in $1.5 \mathrm{ml}$ DMSO. Absorption was measured at $540 \mathrm{~nm}$ in a Shimadzu UV-1601 spectrophotometer, and the cell survival expressed as the percentage of formazan absorption from treated cells in comparison with that of control cells.
Table I. Dark toxicity of ZnPc and irradiation control.

\begin{tabular}{lccc}
\hline $\begin{array}{l}\text { ZnPc } \\
\text { concen- } \\
\text { tration }\end{array}$ & $\begin{array}{c}\text { Incubation } \\
\text { time } \\
\text { (h) }\end{array}$ & $\begin{array}{c}\text { Red light } \\
\text { irradiation } \\
(\mathrm{min})\end{array}$ & $\begin{array}{c}\text { Surviving } \\
\text { fraction }^{\mathrm{a}} \\
(\% \pm \mathrm{SD})\end{array}$ \\
\hline- & - & - & $100 \pm 5$ \\
$5 \times 10^{-7} \mathrm{M}$ & 1 & - & $90.7 \pm 6$ \\
$10^{-6} \mathrm{M}$ & 1 & - & $91.1 \pm 3.89$ \\
$10^{-6} \mathrm{M}$ & 18 & - & $97.36 \pm 4.3$ \\
- & - & 15 & $100 \pm 2.47$ \\
\hline
\end{tabular}

${ }^{\mathrm{a}}$ Mean \pm SD values from at last three different experiments are shown.

Morphological and immunofluorescence studies. Variations in the cell morphology were analyzed using fluorescence microscopy under UV excitation. Cells attached to coverslips were fixed with cold methanol for $5 \mathrm{~min}$, air-dried, stained with $\mathrm{H}-33258(5 \mu \mathrm{g} / \mathrm{ml}, 3 \mathrm{~min})$ in distilled water and mounted in $\mathrm{DePeX}$. For the visualization of Golgi matrix protein GM130, cells grown on coverslips were fixed in 3\% paraformaldehyde at room temperature (RT) for $20 \mathrm{~min}$, washed twice in PBS for $1 \mathrm{~min}$ and permeabilized with $0.1 \%(\mathrm{v} / \mathrm{v})$ Triton X-100 in PBS at RT for 5 min. Cells were incubated with $50 \mu 1$ of primary antibody (mouse monoclonal antiGM130 antibody, BD Transduction Lab.) for $1 \mathrm{~h}$ at $37^{\circ} \mathrm{C}$, washed in PBS and subjected to the secondary antibody [fluorescein isothiocyanate (FITC)-labelled rabbit anti-mouse IgG, Sigma] at $37^{\circ} \mathrm{C}$ for $1 \mathrm{~h}$, and washed again with PBS. After nuclear counterstaining with $5 \mu \mathrm{g} / \mathrm{ml} \mathrm{H}-33258$ for $3 \mathrm{~min}$, preparations were washed with distilled water and mounted in Mowiol. For caspase-2 detection, cells were fixed in paraformaldehyde as above. The coverslips were incubated with $50 \mu 1$ of primary antibody (mouse monoclonal anti- $\mathrm{ICH}_{\mathrm{L}^{-}}$ caspase-2 antibody, BD Transduction Lab.) for $1 \mathrm{~h}$ at $37^{\circ} \mathrm{C}$, washed in PBS for 5 min and incubated with the secondary antibody (Alexa 594-labelled goat anti-mouse IgG, Molecular Probes) at $37^{\circ} \mathrm{C}$ for $1 \mathrm{~h}$. Cells were washed again in PBS, counterstained with H-33258 and mounted in Mowiol.

Microscopy. Microscopic observations were carried out using an Olympus BX61 epifluorescence microscope equipped with an HBO $100 \mathrm{~W}$ mercury lamp and ultraviolet (UV, $365 \mathrm{~nm})$, blue (450-490 nm) and green (546 nm) excitation filters. Photographs were obtained with a digital camera Olympus DP50 and processed using the Adobe Photoshop 8.0 software (Adobe Systems).

\section{Results}

The analysis of cell survival after incubation of A-549 cells with $\mathrm{ZnPc}$ used at different concentrations and incubation times showed that the PS alone did not modify significantly the viability of cell cultures (Table I). Likewise, in the absence of $\mathrm{ZnPc}$, the most prolonged irradiation time used in this work (15 min) did not alter the survival of A-549 cells. 

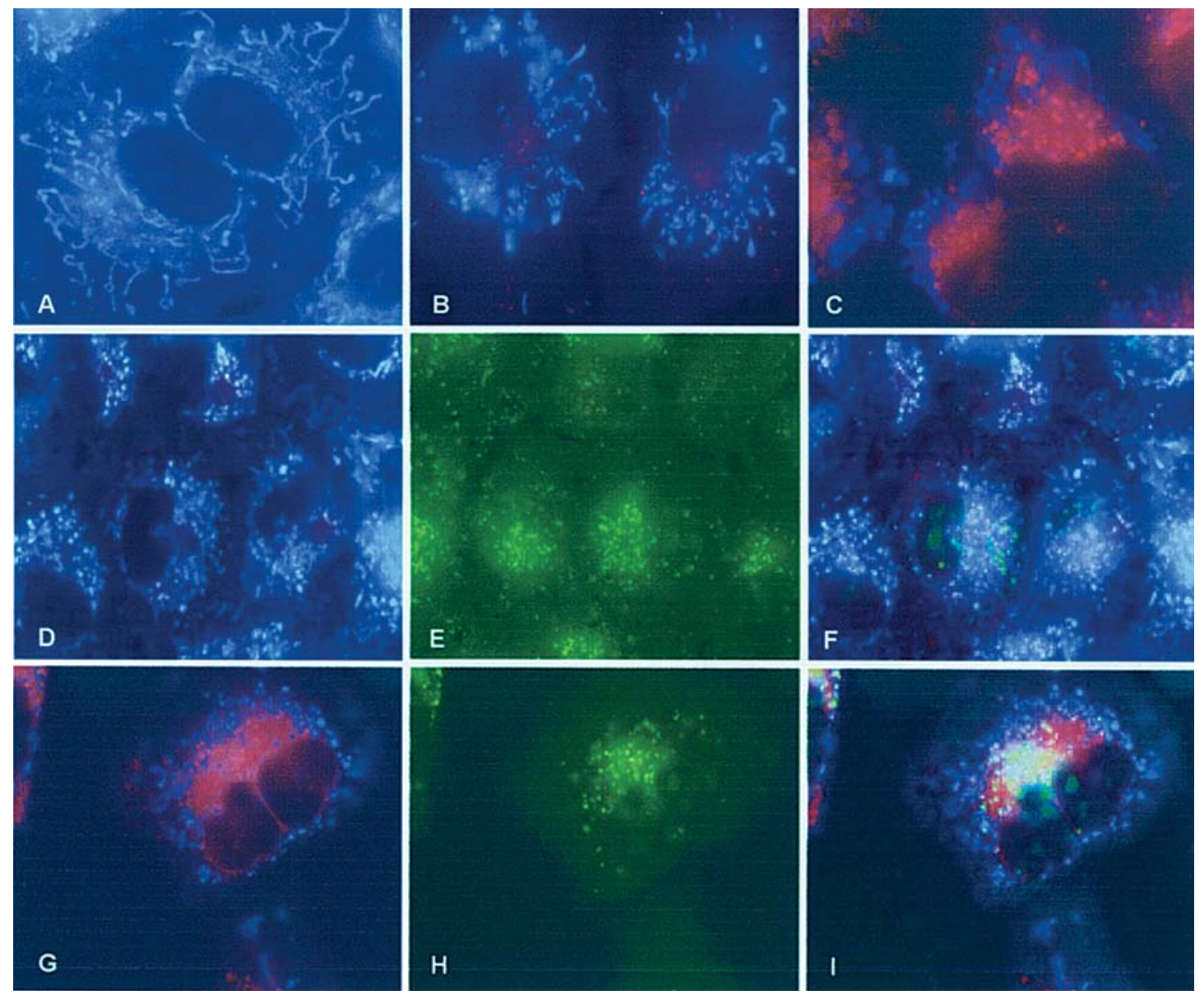

Figure 1. Localization of the photosensitizer ZnPc. A, Control A-549 cells, UV light. B, Cells incubated with $10^{-6} \mathrm{M}$ ZnPc for 3 h, UV light. C, Cells incubated with $10^{-6} \mathrm{M} \mathrm{ZnPc}$ for $18 \mathrm{~h}$, UV light. D-F, A-549 cells incubated with ZnPc for $3 \mathrm{~h}$, washed and re-incubated with AO at low concentration. D, UV light. E, Blue light. F, Overlay of the two previous images. G-I, A-549 cells incubated with ZnPc for $18 \mathrm{~h}$, washed and re-incubated with AO at low concentration. G, UV light. H, Blue light. I, Overlay of the two previous images.

Studies on the subcellular localization of $\mathrm{ZnPc}$ in this cell type after different incubation times are presented in Fig. 1. Fluorescence microscopy images showed that when untreated (control) cells were observed under UV excitation, the blue-white autofluorescence of mitochondria was clearly recognized (Fig. 1A). Following 1-h incubation with $10^{-6} \mathrm{M}$ $\mathrm{ZnPc}$, the red fluorescence of the PS was scarcely visible, whereas after 2-h incubation only some cells appeared with red fluorescence (not shown). When incubated for $3 \mathrm{~h}$, all cells revealed incorporation of $\mathrm{ZnPc}$, which was mainly localized in a polarized perinuclear region, corresponding morphologically with the area of the Golgi apparatus (Fig. 1B). After 18-h incubation, the amount of $\mathrm{ZnPc}$ accumulated within cells increased but the cell region in which it localized was very similar (Fig. 1C). On account of the complete absence of overlay effects between the blue-white autofluorescence of mitochondria and the red fluorescence signal of $\mathrm{ZnPc}$, it can be deduced that the PS does not accumulate within mitochondria.

After 3-h incubation with $10^{-6} \mathrm{M} \mathrm{ZnPc}$ for $3 \mathrm{~h}$, followed by 1 min treatment with the lysosomal marker AO, A-549 cells showed the red fluorescing $\mathrm{ZnPc}$ in the Golgi region (Fig. 1D), whereas lysosomes appeared labelled in green by AO (Fig. 1E; see Materials and methods). When the two images were superimposed (Fig. 1F) no colocalization of the red and green signal was observed, indicating that $\mathrm{ZnPc}$ did not localize within lysosomes. Likewise, after 18-h incubation with $\mathrm{ZnPc}$ followed by AO labelling, no colocalization of the red $\mathrm{ZnPc}$ fluorescence and the green $\mathrm{AO}$ fluorescence was found (Fig. 1G-I).

As the above observations ruled out the localization of $\mathrm{ZnPc}$ in both mitochondria and lysosomes, the fluorescence of $\mathrm{ZnPc}$ was compared with the specific immunofluorescent labelling of the Golgi apparatus by GM130 (Fig. 6A). In this case simultaneous fluorescence signals could not be observed because the procedure used for the detection of GM130 resulted in extraction of the ZnPc signal. When compared with the distribution of GM130, the localization of $\mathrm{ZnPc}$ after 3- or 18-h incubation appeared topographically very well correlated with the immunolabelled Golgi region. Taking into account that $3 \mathrm{~h}$ was the shortest incubation time with $\mathrm{ZnPc}$ that allowed to identify clearly the PS within all cells, this time was selected for most photodynamic treatments.

Fig. 2 shows the rapid decrease of cell survival by 3-15 min red light irradiation of cell cultures previously treated with $10^{-6} \mathrm{M} \mathrm{ZnPc}$ for $3 \mathrm{~h}$. The microscopical analysis of the nuclear morphology by $\mathrm{H}-33258$ staining at variable times after photosensitization revealed that from 5-min irradiation, a significant number of apoptotic nuclei could be observed $6 \mathrm{~h}$ 


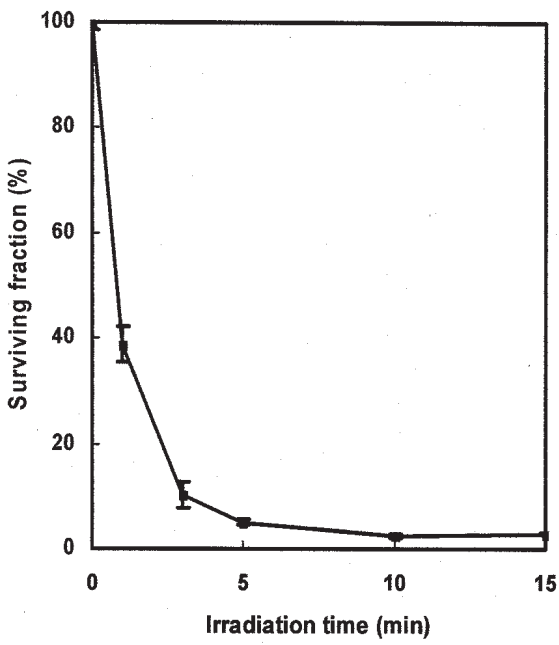

Figure 2. Survival diagram, measured with the MTT test, showing A-549 cells inactivation due to incubation with $10^{-6} \mathrm{M} \mathrm{ZnPc}$ for $3 \mathrm{~h}$ followed by different irradiation times.
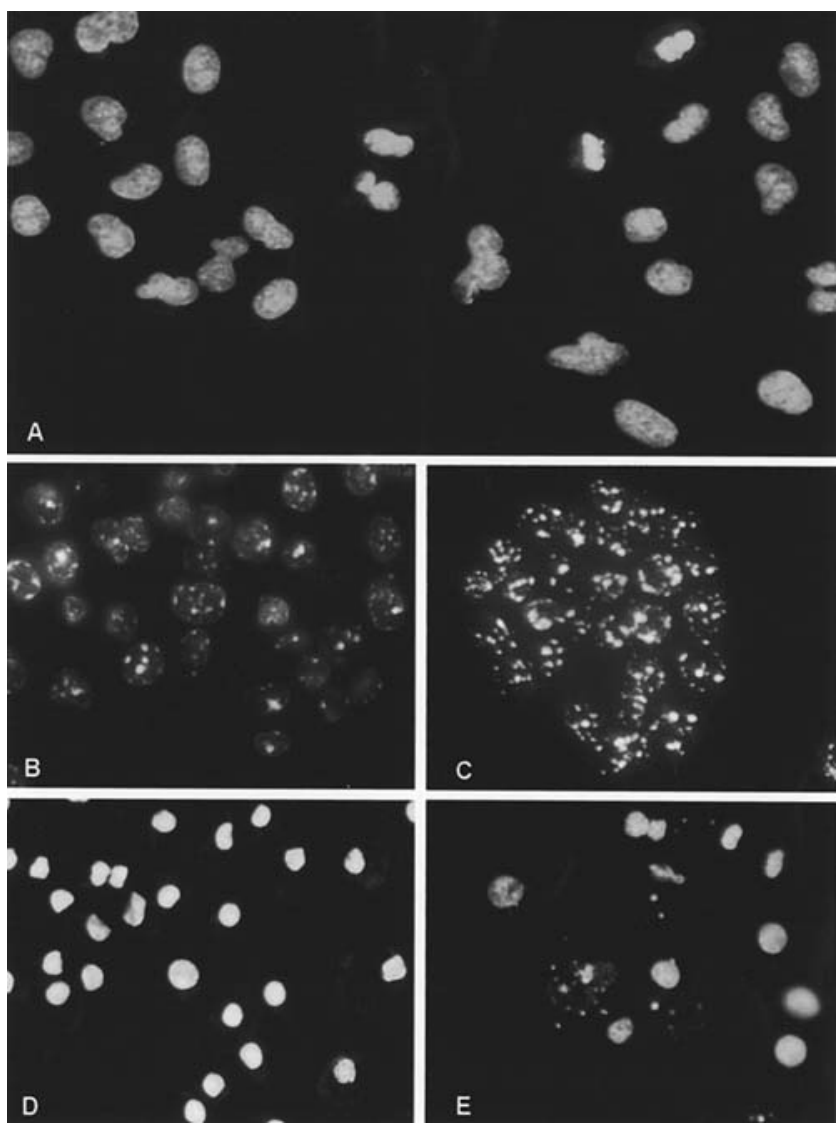

Figure 3. Morphology of A-549 cells after ZnPc incubation and red light irradiation. Cells were stained with H-33258 and visualized under UV exciting light. A, Control cells. B, Cells processed $6 \mathrm{~h}$ after the apoptotic treatment (3-h incubation with $10^{-6} \mathrm{M} \mathrm{ZnPc}$ and 5-min irradiation). C, Cells processed $24 \mathrm{~h}$ after the apoptotic treatment. D, Cells processed $6 \mathrm{~h}$ after the necrotic treatment (1-h incubation with $5 \times 10^{-7} \mathrm{M} \mathrm{ZnPc}$ and 5-min irradiation). E, Cells processed after $24 \mathrm{~h}$ of the necrotic treatment.

(Fig. 3B) and $24 \mathrm{~h}$ later (Fig. 3C). On the contrary, 1-h incubation with a lower concentration of $\mathrm{ZnPc}\left(5 \times 10^{-7} \mathrm{M}\right)$ followed by 5 -min light irradiation clearly resulted in necrotic cell death (Fig. 5). This typical process was also characterized

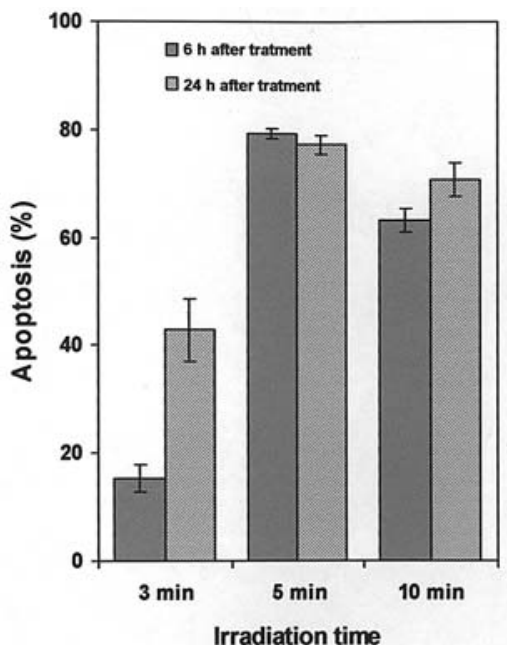

Figure 4. Apoptosis percentage of cell cultures recorded 6 and $24 \mathrm{~h}$ after 3 -h incubation with $10^{-6} \mathrm{M} \mathrm{ZnPc}$ and different irradiation times (3, 5 and $10 \mathrm{~min}$ ). Mean values represent the average of about 2000 cells measured from at least three different experiments.

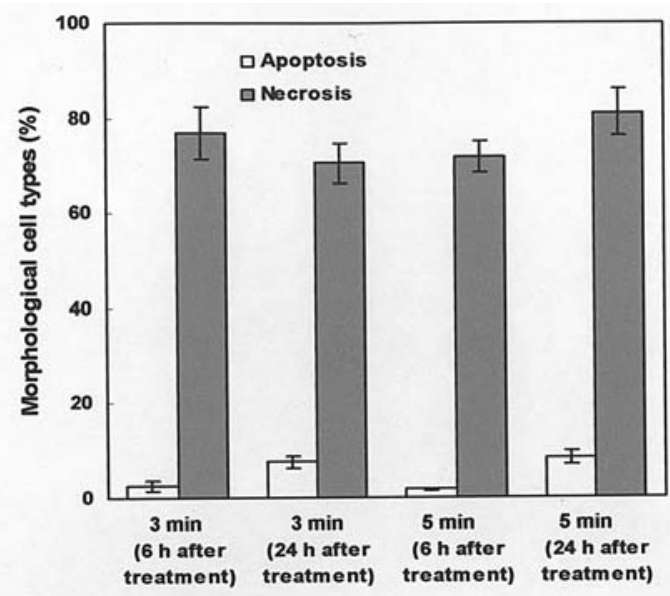

Figure 5. Percentage of apoptosis and necrosis in A-549 cells incubated with $5 \times 10^{-7} \mathrm{M} \mathrm{ZnPc}$ for $1 \mathrm{~h}$, irradiated 3 or $5 \mathrm{~min}$, and observed 6 and $24 \mathrm{~h}$ after photodynamic treatment. On each slide an average of 2000 cells was counted (the values correspond to the mean values measured in at least three different experiments)

by $\mathrm{H}-33258$ fluorescence, first showing reduction of nuclear size and pyknosis $6 \mathrm{~h}$ later (Fig. 3D). Nuclear disintegration with formation of numerous bright fluorescing granules of variable size was observed $24 \mathrm{~h}$ later (Fig. 3E).

The amount of apoptotic A-549 cells after 3-h incubation with $10^{-6} \mathrm{M} \mathrm{ZnPc}$ and irradiation for 3, 5, and $10 \mathrm{~min}$ is shown in Fig. 4. Cell counting was performed 6 and $24 \mathrm{~h}$ following photodynamic treatments. Under these conditions, the highest number of apoptotic cells was observed using 5-min irradiation. These results contrast with those obtained using $5 \times 10^{-7} \mathrm{M} \mathrm{ZnPc}$ for $1 \mathrm{~h}$ and irradiation for 3 and $5 \mathrm{~min}$ (Fig. 5), showing a very low amount of apoptotic cells 6 and $24 \mathrm{~h}$ after the photodynamic treatment. In the same figure, the high percentage of necrotic cell death is also shown for comparative purposes.

Morphological changes in the specifically stained Golgi apparatus at different times after photodynamic treatments 

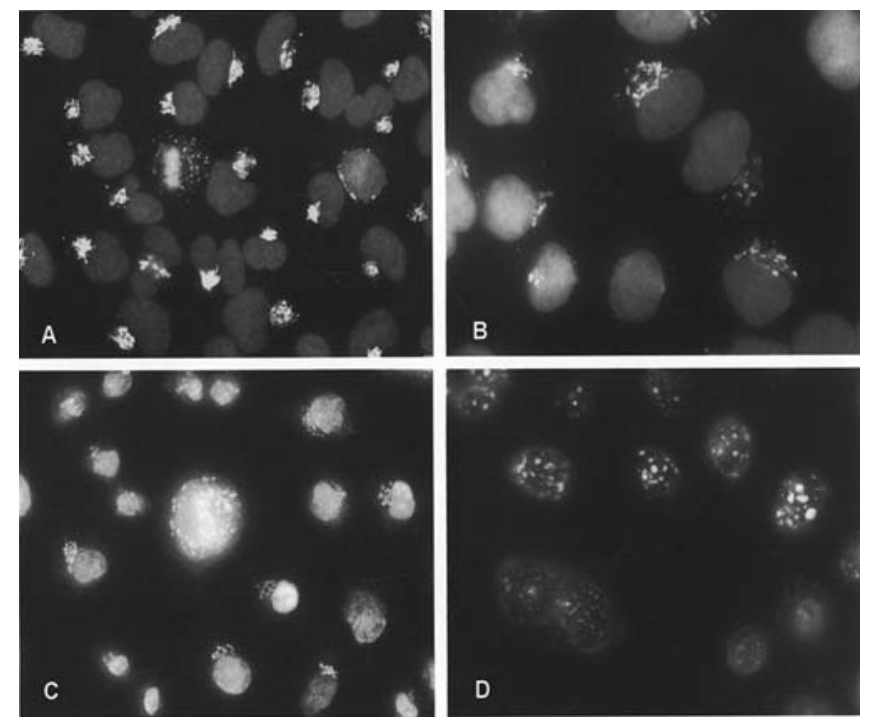

Figure 6. Cells showing indirect immunofluorescence against GM130 and H-33258 counterstaining. Merged images were obtained from the excitation with UV and blue light. A, Control cells. B, Cells observed immediately after 3-h incubation with $10^{-6} \mathrm{M} \mathrm{ZnPc}$ and $5 \mathrm{~min}$ red light irradiation. C, $30 \mathrm{~min}$ after treatment. D, $6 \mathrm{~h}$ after treatment.
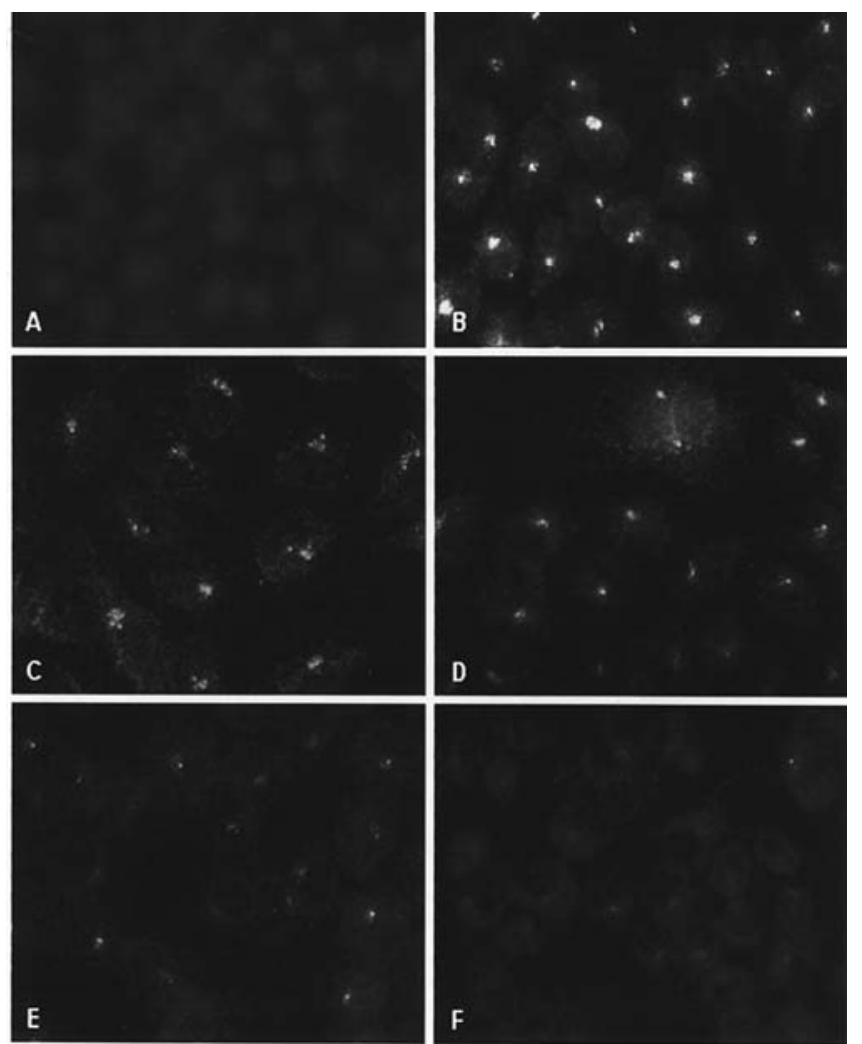

Figure 7. A-549 cells incubated $3 \mathrm{~h}$ with $10^{-6} \mathrm{M} \mathrm{ZnPc}$, irradiated for $5 \mathrm{~min}$ and processed for revealing caspase- 2 by indirect immunofluorescence at different times. A, Control cells. B, Cells processed immediately after the treatment. C-F, Cells processed $15 \mathrm{~min}, 30 \mathrm{~min}, 3 \mathrm{~h}$ and $6 \mathrm{~h}$ after the treatment, respectively.

with $10^{-6} \mathrm{M} \mathrm{ZnPc}$ and 5-min irradiation is shown in Fig. 6. It can be clearly observed that, although slightly less compact, the integrity of the Golgi apparatus was mantained immediately after the treatment as well as 15 min later (Fig. 6A and B).
However, the Golgi labelling became subtle and more disperse 30 min after treatments (Fig. 6C), and $6 \mathrm{~h}$ later it was practically absent (Fig. 6D).

The morphological evolution of the caspase- 2 activation in function of the elapsed time after apoptotic photodynamic treatments is observed in Fig. 7. Untreated (control) A-549 cells only showed a very low and diffuse immunofluorescent signal (Fig. 7A). Immediately after the photodynamic treatment, a bright emission was found in the Golgi region (Fig. 7B), which was maintained 15, 30, and 60 min later (Fig. 7C and D). The immunofluorescent labelling of caspase- 2 decreased $3 \mathrm{~h}$ after treatment (Fig. 7E), and finally it was almost negligible $6 \mathrm{~h}$ later (Fig. 7F). In contrast, using photodynamic conditions that induce necrotic cell death, no activation of caspase-2 was found at any time after treatments (data not shown).

\section{Discussion}

Photodynamic treatments applied to cell cultures have become a very useful tool for the study of processes leading to cell death by apoptosis (16-18). With most of the commonly employed PSs, and using adequate incubation time and irradiation doses, PDT treatments induce cell death by apoptosis or necrosis in almost all cell types $(8,10,19,20)$.

In this work, we have carried out a morphological study of the ZnPc subcellular localization in human tumoral A-549 cells, as well as the sequence of events that cause apoptotic death using this second-generation PS. In previous experiments we checked that drug and irradiation doses used separately had no effect on the cell viability.

Localization of $\mathrm{ZnPc}$ in the Golgi apparatus of 4R transformed murine fibroblasts was described by Fabris et al (21). In that work the authors described the kinetics of drug penetration showing a relationship among apoptotic death and drug localization in this organelle for long incubation times. In contrast, for shorter incubation times part of the PS still remained close to the plasma membrane, producing necrotic death in most cells. Present results are in agreement with these observations. Under our experimental conditions, the drug showed a golgian localization, which was confirmed by comparing the fluorescence of $\mathrm{ZnPc}$ within living cells with that obtained by immunofluorescence detection of GM130.

Incubation of cells with $\mathrm{ZnPc}$ for 3 or $18 \mathrm{~h}$ did not result in PS colocalization with lysosomal AO signal or mitochondria autofluorescence. This localization in the Golgi aparatus could be detected in all cells after drug incubation for $3 \mathrm{~h}$. The amount of intracellular $\mathrm{ZnPc}$ increased with 18-h treatment, but its localization did not change. However, it cannot be excluded that this long incubation time also produces drug accumulation in endosome vesicles, some of them being near the cell membrane. Based on these results, we have used an incubation time of $3 \mathrm{~h}$ to characterize the experimental conditions that induce apoptotic cell death. Using this incubation time the PS accumulated in all cells and showed a more selective localization in the Golgi apparatus than following 18-h incubation.

After 3-h incubation with ZnPc and irradiation with different light doses, a rapid decrease of the surviving cell fraction was observed. The analysis of cell morphology 
indicated that the treatment with $10^{-6} \mathrm{M} \mathrm{ZnPc}$ for $3 \mathrm{~h}$ and irradiation for 5 min caused the highest amount of apoptotic cell morphology. This type of cell death was easily characterized with H-33258 monitoring the typical nuclear fragmentation associated to apoptosis (13). This fragmentation appeared $6 \mathrm{~h}$ after treatment and remained $24 \mathrm{~h}$ later. On the contrary, necrosis evolved generating small and pyknotic nuclei clearly visible $6 \mathrm{~h}$ after irradiation. At $24 \mathrm{~h}$ chromatin degradation and severe cellular disorganization were observed.

It is well known that irradiation of PSs within cells generates ROS (mainly ${ }^{1} \mathrm{O}_{2}$ ) that cause oxidative stress and induce cell death via apoptosis or necrosis depending on the treatment dose. As the half-life of ${ }^{1} \mathrm{O}_{2}$ generated in biological media is very short $(<0.04 \mu \mathrm{s})$, with effects only reaching $0.02 \mu \mathrm{m}$ $(12,22)$, the primary damaging action of $\mathrm{ZnPc}$ must occur near the site where it is located. Since $\mathrm{ZnPc}$ appears accumulated in the Golgi apparatus, one can assume that this organelle is the first PDT target. The sequential analysis of the Golgi disorganization under experimental conditions leading to apoptosis revealed that this organelle is affected in very early stages, and that its total disorganization precedes the nuclear alteration. On account of this early disorganization, it is also possible that the Golgi apparatus could be affected by caspases activation, like other organelles such as the endoplasmic reticulum (7).

To check this point we have studied the kinetics of caspase- 2 activation. This protease can be located in the cytoplasm and nucleus. In some cell types it can be located in the Golgi apparatus, more precisely on its cytoplasmatic side $(23,24)$. In the nucleus, caspase-2 seems to act as an initiator after DNA damage (25), but in the Golgi apparatus the enzyme has been described as an effector. When responding to a cellular stress, caspase-2 is activated in the Golgi apparatus, where it degrades golgin-160 and induces a rapid disorganization of this organelle (23). When golgin-160 is cleaved by caspase-2, several fragments can accumulate in the nucleus. This suggests that golgin-160 degradation has other functions than the simple structural alteration of the organelle (26). Mancini et al (23) have concretely demonstrated that caspase-2 acts in Golgi sites that are not accessible to other caspases, suggesting that the Golgi apparatus, like mitochondria, could act as a pro-apoptotic signalling organelle in response to local oxidative stress.

Under our experimental conditions, we have found that caspase- 2 was rapidly activated after photodynamic treatment and preceded the disorganization of the Golgi apparatus. The fluorescent signal of caspase-2, which was not detectable in control cells, appeared immediately after treatment and remained at least for $1 \mathrm{~h}$ before it began to decay. Six hours after treatment, just when the nuclear morphology is clearly apoptotic, the signal of caspase-2 is practically undetectable. The expression of nuclear caspase- 2 was not observed at any of the studied times. This sequence of reactions seems to indicate that the primary target of the photodynamic treatment would be pro-caspase-2 located in the Golgi apparatus. The proenzyme can then transform into caspase- 2 that would act on golgin-160 producing the organelle disorganization. Under necrotic treatments, the activation of caspase- 2 was not detected at any time after treatment.
In conclusion, the Golgi apparatus could act as a trigger of apoptotic cell death by selective degradation of some structural proteins catalyzed by caspases, mainly by caspase- 2 . These results support previous findings demonstrating that different caspases can act on different organelles detecting stress signals and degrading specific proteins that can stimulate or inhibit the apoptotic process (7).

In this sense cells could possess several pro- and antiapoptotic signal triggers in their subcellular compartments, whose activation and balance can finally determine the cell survival or cell death. Therefore, it is obvious that the precise knowledge of the mechanisms of cell destruction by antitumoral therapies, including PDT, will improve their effectiveness. Morphological and cytochemical studies on cultured cells provide a rapid, simple and suitable method to characterize the mechanisms of the specific response of each tumoral cell line to each PS.

\section{Acknowledgements}

This study was supported by a grant from the Dirección General de Investigación Científica y Técnica (SAF2002-04034 C02-01), Spain. J.C.S. is a scientific member of the Consejo Superior de Investigaciones Científicas, Spain.

\section{References}

1. Reed JC: Apoptosis mechanisms: implications for cancer drug discovery. Oncology 18: 11-20, 2004.

2. Ghobrial IM, Witzig TE and Adjei AA: Targeting apoptosis pathways in cancer therapy. Cancer J Clin 55: 178-194, 2005.

3. Asakura T and Ohkawa K: Chemotherapeutic agents that induce mitochondrial apoptosis. Curr Cancer Drug Targ 4: 577-590, 2004.

4. Kim R: Recent advances in understanding the cell death pathways activated by anticancer therapy, Cancer 103: 1551-1560, 2005.

5. Degli Esposti M: Mitochondria in apoptosis: past, present and future. Biochem Soc Trans 32: 493-4955, 2004

6. Mishra NC and Kumar S: Apoptosis: a mitochondrial perspective on cell death. Ind J Exp Biol 43: 25-34, 2005.

7. Ferri KF and Kroemer G: Organelle-specific initiation of cell death pathways. Nat Cell Biol 3: 255-263, 2001.

8. Piette J, Volanti C, Vantieghem A, Matroule JY, Habraken Y and Agostinis P: Cell death and growth arrest in response to photodynamic therapy with membrane-bound photosensitizers. Biochem Pharmacol 15: 1651-1659, 2003.

9. Stockert JC, Juarranz A, Villanueva A, Nonell S, Horobin RW, Soltermann AT, Durantini EN, Rivarola V, Colombo LL, Espada $\mathrm{J}$ and Cañete $\mathrm{M}$ : Photodynamic therapy: selective uptake of photosensitizing drugs into tumor cells. Curr Top Pharmacol 8: 185-217, 2004.

10. Villanueva A, Durantini EN, Stockert JC, Rello S, Vidania R, Cañete M, Juarranz A, Arranz R and Rivarola V: Photokilling of cultured tumour cells by the porphyrin derivative CF3. Anticancer Drug Des 16: 279-290, 2001.

11. Cañete M, Ortega C, Gavalda A, Cristóbal J, Juarranz A, Nonell S, Teixido J, Borrell JI, Villanueva A, Rello S and Stockert JC: Necrotic cell death induced by photodynamic treatment of human lung adenocarcinoma A-549 cells with palladium(II)tetraphenylporphycene. Int J Oncol 24: 1221-1228, 2004.

12. Moan J and Berg K: The photodegradation of porphyrins in cells can be used to estimate the lifetime of singlet oxygen. Photochem Photobiol 53: 549-553, 1991.

13. Rello S, Stockert JC, Moreno V, Gamez A, Pacheco M, Juarranz A, Cañete M and Villanueva A: Morphological criteria to distinguish cell death induced by apoptotic and necrotic treatments. Apoptosis 10: 201-208, 2005.

14. Ginevra F, Biffanti S, Pagnan A, Biolo R, Reddi E and Jori G: Delivery of the tumour photosensitizer zinc(II)-phthalocyanine to serum proteins by different liposomes: studies in vitro and in vivo. Cancer Lett 49: 59-65, 1990. 
15. Merlin JL, Azzi S, Lignon D, Ramacci C, Zeghari N and Guillemin F: MTT assays allow quick and reliable measurement of the response of human tumour cells to photodynamic therapy. Eur J Cancer 28: 1452-1458, 1992.

16. Vantieghem A, Assefa Z, Vandenabeele P, Declercq W, Courtois S, Vandenheede JR, Merlevede W, De Witte P and Agostinis P: Hypericin-induced photosensitization of HeLa cells leads to apoptosis or necrosis. Involvement of cytochrome $\mathrm{c}$ and procaspase-3 activation in the mechanism of apoptosis. FEBS Lett 440: 19-24, 1998.

17. Usuda J, Azizuddin K, Chiu SM and Oleinick N: Association between the photodynamic loss of $\mathrm{Bcl}-2$ and the sensitivity to apoptosis caused by phthalocyanine photodynamic therapy. Photochem Photobiol 78: 1-8, 2003.

18. Xue LY, Chiu SM, Fiebig A, Andrews DW and Oleinick N: Photodamage to multiple Bcl-xL isoforms by photodynamic therapy with the phthalocyanine photosensitizer Pc 4. Oncogene 22: 9197-9204, 2003.

19. Noodt BB, Berg K, Stokke T, Peng Q and Nesland JM: Apoptosis and necrosis induced with light and 5-aminolaevulinic acidderived protoporphyrin IX. Br J Cancer 74: 22-29, 1996.

20. Almeida RD, Manadas BJ, Carvalho AP and Duarte CB: Intracellular signaling mechanisms in photodynamic therapy. Biochim Biophys Acta 1704: 59-86, 2004.
21. Fabris C, Valduga G, Miotto G, Borsetto L, Jori G, Garbisa S and Reddi E: Photosensitization with zinc (II) phthalocyanine as a switch in the decision between apoptosis and necrosis. Cancer Res 61: 7495-7500, 2001

22. Dolmans DE, Fukumura D and Jain RK: Photodynamic therapy for cancer. Nat Rev Cancer 3: 3870-3877, 2003.

23. Mancini M, Machamer CE, Roy S, Nicholson DW, Thornberry NA, Casciola-Rosen LA and Rosen A: Caspase-2 is localized at the Golgi complex and cleaves golgin-160 during apoptosis. J Cell Biol 149: 603-612, 2000.

24. O'Reilly LA, Ekert P, Harvey N, Marsden V, Cullen L, Vaux DL, Hacker G, Magnusson C, Pakusch M, Cecconi F, Kuida K, Strasser A, Huang DC and Kumar S: Caspase-2 is not required for thymocyte or neuronal apoptosis even though cleavage of caspase-2 is dependent on both Apaf-1 and caspase-9. Cell Death Differ 9: 832-841, 2002.

25. Machamer CE: Golgi disassembly in apoptosis: cause or effect? Trends Cell Biol 13: 279-281, 2003.

26. Hicks SW and Machamer CE: The NH2-terminal domain of golgin-160 contains both Golgi and nuclear targeting information. J Biol Chem 277: 35833-35839, 2002. 